\title{
Studi Deskriptif: Filsafat Agama Dan Ruang Lingkup Kajian Pembahasannya
}

\author{
Iskandar Zulkarnaen \\ Institut Dirosat Islamiyah Al-Amien (IDIA) Prenduan Sumenep \\ iskandar@idia.ac.id
}

\begin{abstract}
Abstrak: Istilah filsafat dan agama mengandung pengertian yang dipahami secara berlawanan oleh banyak orang. Filsafat dalam cara kerjanya bertolak dari akal, sedangkan agama bertolak dari wahyu. Oleh sebab itu, hal ini memiliki banyak kaitannya dengan berfikir sementara agama banyak kaitannya dengan pengalaman. Filsafat membahas sesuatu dalam rangka melihat kebenaran yang diukur, apakah sesuatu itu logis atau bukan. Agama tidak selalu mengukur kebenaran dari segi logisnya karena agama kadangkala tidak terlalu memperhatikan aspek logisnya. Dalam penelitian ini, peneliti menggunakan penelitian kualitatif-deskriptif dengan jenis penelitian pustaka." Dimana peneliti membaca dan mengalisis literatur-literatur baik buku, jurnal dan lain-lainnya dengan penuh teliti dan dapat dipertanggung jawabkan secara akademik tulisan ini. Dalam penelitian ini dapatlah peneliti simpulkan bahwa filsafat agama merupakan sebuah kajian tentang keyakinan seseorang terhadap agama yang dianutnya dengan didasari pemikiran logis dan dilakukan secara radikal.
\end{abstract}

Kata Kunci: Filsafat, Agama, Kegunaan Filsafat Agama

\begin{abstract}
The terms philosophy and religion contain understandings that are understood counterintuitively by many. Philosophy in the way it works departs from reason, while religion departs from revelation. Therefore, this has a lot to do with thinking while religion has a lot to do with experience. Philosophy discusses something in order to see the measured truth, whether something is logical or not. Religion does not always measure truth logically because religion sometimes does not pay much attention to its logical aspects. In this study, researchers used qualitative-descriptive research with a type of library research. Where researchers read and analyzed the literature both books, journals and others carefully and can be accounted for academically this writing. In this study, researchers concluded that religious philosophy is a study of one's belief in religion based on logical thinking and conducted radically.
\end{abstract}

Keywords: Philosophy, Religion, the Uses of Philosophy of Religion 


\section{DIROSAT \\ Journal of Islamic Studies \\ Volume 6, No. 22021}

ISSN: 2541-1667 (print); 2541-1675 (online)

\section{Pendahuluan}

Istilah filsafat dan agama mengandung sebuah pengertian yang dapat dipahami secara berlawanan oleh banyak orang. Filsafat dalam cara kerjanya berasal dari akal, sedangkan agama berasal dari wahyu. Filsafat banyak kaitan dengan berfikir sementara agama banyak berkaitan dengan pengalaman. Filsafat adalah salah satu bidang kajian yang mengkaji cara berpikir sampai mendalam tentang hakikat sesuatu. Filsafat merupakan induk dari berbagai ilmu pengetahuan. Oleh karena ada salah cabang filsafat salah satunya adalah epistimologi.

Filsafat membahas sesuatu dalam rangka melihat kebenaran yang diukur, apakah sesuatu itu logis atau tidak logis. Agama tidak selalu mengukur kebenaran dari segi logisnya karena agama kadang-kadang tidak terlalu memperhatikan aspek logisnya. ${ }^{\prime \prime}$ Perbedaan tersebut menimbulkan konflik berkepanjangan antara orang yang cenderung berfikir filosofis dengan orang yang berfikir agamis, pada hal filsafat dan agama mempunyai fungsi yang sama kuat untuk kemajuan, keduanya tidak bisa dipisahkan dari kehidupan manusia. ${ }^{2}$ Untuk menelusuri seluk-beluk filsafat dan agama secara mendalam perlu diketahui terlebih dahulu apa yang dimaksud dengan filsafat agama.

Dalam kehidupan masyarakat di era kontemporer ini, filsafat menjadi ilmu baru yang mungkin dianggap asing oleh sebagian orang awam. Jujur dalam hal ini penulispun mengakui bahwa filsafat baru terdengar sekarang ketika menjalani bangku perkuliahan meskipun nama-nama filsuf terkenal seperti Aristoteles maupun Plato sudah seringkali didengar. ${ }^{3}$ Inilah yang menyebabkan filsafat kurang menjadi alternatif dalam pendekatan masalah kehidupan. Padahal jika kita kaji, intisari filsafat adalah mendalami suatu masalah untuk menemukan solusi yang rasional dan universal. ${ }^{4}$

Agama menjadi hal umum yang sudah dikenal masyarakat terutama Indonesia sejak dulunya dan menjadi warisan mutlak masyarakatnya. Sehingga tidak heran jika setiap masalah selalu dicarikan solusi melalui pendekatan Agama. ${ }^{5}$ Dari penjelasan diatas ini, penulis akan membahas tentang filsafat agama beserta kajian ruang lingkup pembahasannya. Agar ini menjadi sebuah dasar berfilsafat bagi para pembaca untuk memahami lebih dalam tentang korelasi filsafat dan agama secara baik. Dari itu juga, "ini merupakan disiplin ilmu pengetahuan yang mengangkat pemikiran rasional yaitu filsafat dan Agama yang merupakan keyakinan jiwa dengan ajarannya bahkan sulit dicerna dengan akal sehat, tetapi menjadi sebuah kebutuhan mutlak manusia. Ada satu kesamaan antara ajaran keduanya yang menarik, yaitu adanya hubungan kausalitas atau hubungan sebab akibat dalam keberlangsungan hidup manusia.

\section{Metode Penelitian}

Dalam menjelaskan kajian ini, penulis akan memakai sebuah pendekatan kualitatif deskriptif dengan jenis penelitian pustaka (Library Research). ${ }^{6}$ Karena objek kajian ini merupakan sebuah gagasan tentang filsafat agama dan ruang lingkup kajiannya.

\footnotetext{
${ }^{1}$ Kemas Badarudin, Filsafat Pendidikan Islam (Yogyakarta: Pustaka Pelajar, 2009). h. 3.

2 Wan Mohd Nor Wan Daud, Filsafat Dan Praktek Pendidikan Islam Syed Naquib Al-Attas (Bandung: Mizan, 2003). h. 45.

${ }^{3}$ Sondang P. Siagian, Filsafat Administrasi (Jakarta: Haji Masagung, 1987). h. 10

${ }^{4}$ Budi Handriyanto, Islamisasi Sains (Jakarta: Pustaka Al-Kautsar, 2010). h. 17.

5 Ismail SM, Paradigma Pendidikan Islam Prof. Dr. Syed Muhammad Naquib Al-Attas (Yogyakarta, 1999). h. 56

${ }^{6}$ Sugiono, Metodologi Penelitian Pendidikan Kuantitatif-Kualitatif Dan R\&D (Bandung: Alfabeta, 2010).
} 


\section{DIROSAT \\ Journal of Islamic Studies \\ Volume 6, No. 22021}

ISSN: 2541-1667 (print); 2541-1675 (online)

Dalam mendapatkan berbagai sumber data ini, peneliti menggunakan dua cara yang dilakukan: "pertama, data primer dimana peneliti membaca dan mengkaji berbagai buku utama yakni filsafat agama dan ruang lingkupnya Kedua, data sekunder diantaranya literatur buku, penelitian terdahulu dan segala artikel-artikel jurnal yang berkaitan dengan judul yang akan diteliti oleh peneliti berkenaan dengan filsafat agama Sedangkan teknik analisis data yang digunakan dalam kajian ini menggunakan reduksi data, penyajian data dan menarik kesimpulan. ${ }^{7}$

\section{Pengertian Filsafat Agama}

filsafat berasal dari bahasa Yunani yaitu philosophia-philein artinya cinta, mencintai, philos pecinta, sophia kebijaksanaan atau hikmat. Dengan itu, filsafat artinya "cinta akan kebijaksanaan". ${ }^{8}$ Cinta artinya hasrat yang besar atau yang sungguh-sungguh. Kebijaksanaan artinya kebenaran sejati atau kebenaran yang sesungguhnya. Filsafat berarti hasrat atau keinginan yang sungguh akan kebenaran sejati.

Secara umum filsafat adalah suatu ilmu yang berusaha menyelidiki hakikat segala sesuatu untuk memperoleh kebenaran. Filsafat disebut sebagai: suatu usaha untuk berpikir yang radikal dan menyeluruh, suatu cara berpikir yang mengupas sesuatu sedalam-dalamnya. Hal yang membawa usahanya itu kepada suatu kesimpulan universal dari kenyataan partikular atau khusus, dari hal yang tersederhana sampai yang terkompleks. ${ }^{9}$

Filsafat merupakan Ilmu tentang hakikat. Di sinilah kita memahami perbedaan mendasar antara filsafat dan ilmu (spesial) atau sains. Ilmu membatasi wilayahnya sejauh alam yang dapat dialami, dapat diindera, atau alam empiris. Ilmu menghadapi soalnya dengan pertanyaan bagaimana dan apa sebabnya. Filsafat mencakup pertanyaanpertanyaan mengenai makna, kebenaran, dan hubungan logis di antara ide-ide dasar (keyakinan, asumsi dan konsep) yang tidak dapat dipecahkan dengan ilmu empiris. Filsafat ialah hasil daya upaya manusia dengan akal budinya untuk memahami secara radikal hakikat yang ada. ${ }^{10}$

Filsafat juga dapat diartikan sebagai cinta kebijaksanaan atau cinta kebenaran, yaitu upaya untuk selalu mencari kebenaran dengan menggunakan akal, pengertian filsafat yang demikian ini antara tradisi pemikiran barat dan pemikiran timur berbeda. Dalam tradisi pemikiran barat, cinta kebenaran (orang yang bijaksana) adalah orang yang mengedepankan kecerdasan intelektual. ${ }^{11}$ Sedangkan menurut tradisi pemikiran timur, orang bijaksana adalah orang yang mengedepankan kecerdasan emosi. Jadi, secara umum kata filsafat merupakan suatu kata yang menunjukkan pada upaya manusia untuk mencari keutamaan hidup. Hal ini terkait dengan upaya manusia untuk meningkatkan harkat dan martabat kemanusiaan melalui berbagai pemikiran agar manusia lebih berbudaya, beradab, dan menikmati hidup. ${ }^{12}$ Sedangkan Agama adalah sistem yang mengatur tata keimanan (kepercayaan) dan peribadatan kepada Tuhan Yang Mahakuasa

\footnotetext{
${ }^{7}$ Lexy J. Moleong, Metodologi Penelitian Kualitatif (Bandung: Remaja Rosdakarya, 2005).

8 Burhanuddin Salam, Pengantar Filsafat (Jakarta: PT. Bumi Aksara, 2012). h. 46.

${ }_{9}^{9}$ Abd. Wahid, 'Korelasi Agama, Filsafat Dan Ilmu', Jurnal Substantia, 14.2 (2012), 224-331.

10 Burhanuddin Salam, Pengantar Filsafat. h. 55.

11 Komaruzaman, "Studi Pemikiran Muhammad Abduh Dan Pengaruhnya Terhadap Pendidikan Di Indonesia," Tarbawi: Jurnal Keilmuan Manajemen Pendidikan 3, no. 01 (2017): 90-101.

12 Nurlaelah Abbas, "Muhammad Abduh: Konsep Rasionalisme Dalam Islam," Jurnal Dakwah Tabligh 15, no. 1 (2014): 51-68.
} 


\section{DIROSAT \\ Journal of Islamic Studies \\ Volume 6, No. 22021}

ISSN: 2541-1667 (print); 2541-1675 (online)

serta tata kaidah yang berhubungan dengan pergaulan manusia dan manusia serta lingkungannya. Kata agama juga berasal dari bahasa Sanskerta yang berarti tradisi. ${ }^{13}$

Agama semakna juga dengan kata "ad-Din" (bahasa arab) yang berarti cara, adat kebiasaan, peraturan, undang-undang taat dan patuh, mengesakan tuhan, pembalasan, perhitungan, hari kiamat dan nasihat [2]. Agama menurut agama islam ialah peraturan yang mendorong jiwa untuk memegang aturan Tuhan dalam mencapai kebaikan dunia dan akhirat. ${ }^{14}$ Agama adalah keseluruhan pendapat tentang Tuhan, dunia, hidup, mati, tingkah laku serta baik buruknya yang berdasarkan wahyu. Wahyu adalah penerangan Tuhan secara istimewa kepada manusia secara langsung ataupun tidak langsung (melalui wakil atau utusan). Pada zaman skolastik, filsafat disebut juga dengan filsafat masehi karena didasarkan pada ajaran agama masehi. Walaupun disebut sebagai filsafat masehi tetapi filsafat tetap dalam arti yang sebenarnya, karena berjalan di atas landasan fikiran. Secara lebih khusus dijelaskan dalam buku filsafat skolastik bahwa agama adalah aqidah (kepercayaan) yang diwahyukan dan yang mengharuskan keimanan. Sedangkan filsafat ialah penyelidikan fikiran yang didasarkan atas dalil-dalil fikiran. ${ }^{15}$

Menurut Durkheim dalam buku Gambaran Pertama bagi Penghidupan Keagamaan bahwa Agama adalah alam ghaib yang tidak dapat diketahui oleh akal dan pikiran manusia atau Agama adalah suatu bagian dari pengetahuan yang tidak dapat dicapai oleh ilmupengetahuan biasa dan tidak dapat diperoleh dengan pikiran saja. Menurut al-Syahratani dalam buku Al-Minal wa al- Nihal berpendapat bahwa agama adalah ketaatan dan kepatuhan yang terkadang biasa diartikan sebagai pembalasa dan perhitungan (amal perbuatan di akhirat). ${ }^{16}$ Sehingga dapatlah diambil sebuah penjelasan bahwa filsafat agama adalah sebuah ilmu pengetahuan yang menyelidiki tentang suatu yang berkaitan dengan ketuhanan, alam semesta dan manusia sehingga dapat menghasilkan pengetahuan yang didapat dengan akal logis manusia sesuai dengan tuntunan yang ada dalam ajaran agama.

\section{Hubungan Antar Filsafat Dan Agama}

Terdapat berbagai macam asumsi yang berkaitan dengan hubungan antara filsafat dan agama. Asumsi pertama, manusia sebagai makhluk budaya mampu berspekulasi dan berteori filsafat yang akan menentukan kebudayaannya, bahkan sampai sadar dan jujur mengakui kenyataan Tuhan dan ajaran agama. Asumsi kedua, bahwa dunia kita diciptakan oleh tuhan sebagai suatu yang potensial dapat diperbaiki, diperindah dan diperkaya, sehingga hidup dan penghidupan ini lebih dapat meningkat nilai harganya untuk dihidupi dan dinikmati. ${ }^{17}$ Selanjutnya ia juga membuat perbandingan mengenai jalinan agama dengan filsafat :

1. Agama adalah unsur mutlak dan sumber kebudayaan, sedangkan filsafat adalah salah satu unsur kebudayaan.

2. Agama adalah ciptaan Tuhan, sedangkan filsafat hasil spekulasi manusia.

\footnotetext{
${ }^{13}$ Dedi Supriyadi \& Mustofa Hasan, Filsafat Agama, 1st ed. (Bandung: Pustaka Setia, 2012). h. 5.

14 Syarif Hidayatullah, "Relasi Filsafat Dan Agama (Perspektif Islam)," Jurnal Filsafat 16, no. 2 (2006): 128-148. h. 129.

${ }^{15}$ Hossein Nasr, Islam Dan Nestapa Manusia, ed. Anas Mahyuddin (Bandung: Pustaka Mulia, 1983). h. 23.

${ }^{16}$ Ahmad Iffan, Muhammad Ridho Nur, and Asrizal Saiin, "Konseptualisasi Moderasi Beragama Sebagai Langkah Preventif Terhadap Penanganan Radikalisme Di Indonesia," Perada 3, no. 2 (2020): 187.

${ }^{17}$ Marhaeni Saleh, “Filsafat Agama Dalam Ruang Lingkupnya," Sulesana 6, no. 488 (2012): 2292.
} 


\section{DIROSAT \\ Journal of Islamic Studies \\ Volume 6, No. 22021}

ISSN: 2541-1667 (print); 2541-1675 (online)

3. Agama adalah sumber-sumber asumsi dari filsafat dan ilmu pengetahuan (science), dengan filsafat menguji asumsi-asumsi science.

4. Agama mendahulukan kepercayaan daripada pemikiran, sedangkan filsafat mempercayakan sepenuhnya kekuatan daya pemikiran.

5. Agama mempercayai akan adanya kebenaran dan dogma-dogma agama, sedangkan filsafat tidak mengakui dogma-dogma sebagai kenyataan tentang kebenaran. ${ }^{18}$

Berdasarkan dialog pembahasan diatas, terlihat jelas bahwa peran agama terhadap filsafat ialah meluruskan filsafat yang sifatnya spekulatif kepada kebenaran mutlak yang ada pada agama. Sedangkan peran filsafat terhadap agama ialah membantu keyakinan manusia terhadap kebenaran mutlak pada Tuhany-Nya, dengan pemikiran yang kritis dan logis. Hal ini juga, didukung pula dengan pernyataan bahwa filsafat yang sejati haruslah berdasarkan agama, dan terkandung dalam agama juga. Filsafat dan agama bertujuan untuk hal yang sama yaitu kebenaran. Filsafat dengan wataknya sendiri menghampiri kebenaran, baik tentang alam maupun tentang manusia, yang belum atau tidak dapat dijawab oleh ilmu ataupun tentang Tuhan. Agama dengan karakternya pula memberikan jawaban atas segala persoalan asasi yang dipertanyakan manusia, baik tentang alam maupun tentang manusia dan tentang Tuhan. ${ }^{19}$

Agama lebih banyak dapat dihayati, dipahami, diselami, dan dialami oleh manusia yang berilmu pengetahuan dan berfilsafat luaas dan mendalam. Agama memberikan dorongan (motif), pengarahan dan tujuan kepada filsafat." "Filsafat mendasarkan pada otoritas akal murni secara bebas, sedangkan agama mendasarkan diri pada otoritas wahyu. ${ }^{20}$ Objek kajian filsafat adalah alam, manusia, dan Tuhan sedangkan objek kajian agama adalah Tuhan. Filsafat sama halnya dengan agama, sama-sama mengkaji tentang kebajikan, tentang Tuhan, baik dan buruk, itulah sebabnya filsafat mempunyai hubungan yang dekat dengan agama. Hal-hal yang tidak terjangkau oleh akal pikiran (filsafat) akan terjawab melalui wahyu (agama), begitu juga filsafat, membahas persoalan-persoalan yang tidak terjawab oleh ilmu pengetahuan. Kebenaran yang diperoleh oleh filsafat adalah murni hasil pemikiran manusia dengan cara perenungan yang mendalam (radikal) tentang hakikat segala sesuatu (metafisika). Sdangkan agama mengajarkan kebenaran melalui wahyu atau kitab suci berupa firman Tuhan. ${ }^{21}$ Adapun kriteria yang harus dimiliki oleh suatu agama yaitu:

1) Adanya sistem keyakinan/kepercayaan terhadap Tuhan Sebagai Zat Maha Pencipta dan Maha Suci.

2) Adanya sistem persembahan berisi peraturan tata cara pelaksanaan ibadah/peribadatan manusia terhadap Tuhan yang telah diyakininya.

3) Adanya kitab suci yang menghimpun hukum/peraturan ketetapan Tuhan sebagai pedoman bagi para pemeluknya.

4) Adanya Rasul utusan Tuhan yang menyampaikan ajaran Tuhan itu kepada manusia agar memenuhi segala perintah-Nya dan menjauhi segala laranganNya. ${ }^{22}$

Sedangkan kalau kita tinjau dari asal atau sumbernya dibagi dua bagian yaitu:

${ }^{18}$ A. Susanto, Filsafat Ilmu (Jakarta: PT. Bumi Aksara, 2010). h. 68-69.

${ }^{19}$ Abu Tamrin, "Relasi Ilmu, Filsafat Dan Agama Dalam Dimensi Filsafat Ilmu," SALAM: Jurnal Sosial dan Budaya Syar-i 6, no. 1 (2019): 71-96.

${ }^{20}$ Abd. Wahid, "Korelasi Agama, Filsafat Dan Ilmu."

${ }^{21}$ Dedi Supriyadi \& Mustofa Hasan, Filsafat Agama. h. 22-23.

22 A. Susanto, Filsafat Ilmu. h. 134. 


\section{DIROSAT \\ Journal of Islamic Studies \\ Volume 6, No. 22021}

ISSN: 2541-1667 (print); 2541-1675 (online)

1. Agama Samawiyah ialah agama yang datangnya dari Allah dalam wujud wahyu yang ciri pokoknya Tauhid dan adanya Rasul yang ditugaskan untuk menyampaikan kepada manusia. Yang tergolong agama Samawiyah ini ialah agama Yahudi, Nasrani dan Islam.

2. Agama Ardhiyah yaitu agama yang dibentuk oleh budaya/kebudayaan manusia. Agama semacam ini sering berpaham animisme dan dinamisme. Konsepsi agamanya selalu berubah-ubah menurut dan sesuai dengan keinginan masyarakat pemeluknya. Dan yang tergolong agama Ardhiyah ini adalah agama Hindu, Buddha, konghucu, Shinto dan lain-lain. ${ }^{23}$

Dengan beberapa perbedaan agama dan juga kriteria yang dijelaskan diatas. Maka sebenarnya agama memiliki beberapa fungsi sebagai berikut:

a. Sumber pedoman hidup bagi individu maupun kelompok.

b. Mengatur tata cara hubungan manusia dengan Tuhan dan manusia dengan manusia.

c. Merupakan tuntutan tentang prinsip benar atau salah.

d. Pedoman mengungkapkan rasa kebersamaan.

e. Pedoman perasaan keyakinan.

f. Pedoman keberadaan.

g. Pengungkapan estetika (keindahan).

h. Pedoman rekreasi dan hiburan.

i. Memberikan identitas kepada manusia sebagai umat dari suatu agama. ${ }^{24}$

\section{Posisi Agama Sebagai Objek Kajian Filsafat}

Secara mendasar, setiap ilmu pengetahuan memiliki dua macam objek, Yakni objek materil dan objek formal. Objek materil yaitu suatu objek yang dijadikan sasaran penyelidikan. Seperti, tubuh manusia merupakan objek materil dari ilmu kedokteran. sedangkan objek formal adalah cara pandang (worldview) tertentu tentang objek materil yang diselidiki. Seperti, pendekatan empiris dan indiktif dalam ilmu kedokteran. ${ }^{25}$

Filsafat adalah sebuah proses berfikir yang radikal dan sistematis dengan juga memiliki dua objek yaitu materil dan juga formal. Adapun objek materil filsafat adalah segala sesuatu yang ada. Adapun segala sesuatu yang ada disini, yaitu sesuatu yang tampak dan tidak tampak. Yang tampak dianalisis secara empiris dan yang tidak tampak dianalisis secara metafisik. ${ }^{26}$

Adapun pokok persoalan yang dijelaskan dalam agama adalah sebuah eksistensi Tuhan, Manusia dan hubungan antara manusi dengan Tuhan-Nya. Yang mana dalam hal ini merupakan aspek metafisik, sedangkan hubungan manusia dengan mahluk yang lainnya seperti alam semesta, tumbuhan dan hewan termasuk pada katerori aspek fisik. ${ }^{27}$ Dengan demikian, filsafat membahas agama harus difokuskan terlebih dahulu pada aspek metafisiknya dari pada aspek fisikanya. Karena aspek fisik, biasanya akan dijelaskan dengan berbagai macam ilmu yang lainnya. Seperti, psikologi, biologi, sosiologi, antropologi dan ilmu-ilmu yang lainnya.

Ditinjau dari segi objek material fisafat agama objenya berdimensi metafisik dan fisik. Sedangkan ditinjau dari dari objek formalnya adalah udut pandang yang

${ }^{23}$ Abd. Wahid, "Korelasi Agama, Filsafat Dan Ilmu." h. 229

24 Tamrin, "Relasi Ilmu, Filsafat Dan Agama Dalam Dimensi Filsafat Ilmu." h. 80.

25 Burhanuddin Salam, Pengantar Filsafat. 45

26 Dedi Supriyadi \& Mustofa Hasan, Filsafat Agama. h. 15.

27 Iffan, Nur, and Saiin, "Konseptualisasi Moderasi Beragama Sebagai Langkah Preventif Terhadap Penanganan Radikalisme Di Indonesia.” h. 187. 


\section{DIROSAT \\ Journal of Islamic Studies \\ Volume 6, No. 22021}

ISSN: 2541-1667 (print); 2541-1675 (online)

menyeluruh, rasional, objektif, bebas, dan radikal tentang pokok-pokok agama. Yang dimaksud pendekatan menyeluruh adalah usaha menjaelaskan pokok-pokok ajaran agama secara umum, tidak mengenai ajaran agama tertentu saja. Pendekatan menyeluruh juga berarti suatu proses untuk mendapatkan gambaran yang utuh tentang suatu masalah yang dibahas. Agama tidak dibahas secara parsial dan terpilah-pilah, tetapi mancakup semua pemikiran dan ajaran. ${ }^{28}$ Pembahasan mengenai Tuhan misalnya tidak saja dikemukakan pendapat yang mendukung adanya Tuhan tetapi juga pendapat yang meragukanNya, dan bah kan juga yang menolakNya. Selain itu, Tuhan yang dibahas tidak hanya Tuhan agama Yahudi, Kristen, dan Islam, tetapi Tuhan semua agama.

Pendekatan objektif adalah metode yang sesuai dengan realitas objektif yang meminimalkan subjetifitas pembahasan. Pendekatan objektif ini sangat diperlukan dalam filsafat agama dikarenakan yang pada dasarnya aspek subjetifitas dalam agama sangat kuat sekali. Apalagi, semua pembahasan filsafat agama adalah orang-orang yang telah menganut agama tertentu. Karena itu, pembahasan filsafat agama perlu ditekankan pada segi objektfitas, meskipun tidak dinafikkan sama sekali masuknya unsur subjektifitas tadi. Namun dalam pembahasan dasar agama yang bersifat umum diusahakan se-objektif mungkin. ${ }^{29}$

Berfikir secara bebas dalam membahas dasar-dasar agama dapat mengambil dua bentuk yaitu: Pertama, Membahas dasar-dasar agama secara analitis dan kritis tanpa terikat pada ajaran-ajaran tanpa ada tujuan untuk menyatakan kebenaran suatu agama itu sendiri. Kedua, Membahas dasar-dasar agama secara analitis dan kritis dengan maksud untuk menyatakan kebenaran ajaran-ajaran agama, atau sekurang-kurangnya untuk menjelaskan bahwa apa yang daiajarkan agama tidak bertentangan dengan logika." ${ }^{30}$ Filsafat agama pada hakekatnya adalah pembahasan yang mendalam tentang ajaran dasar agama. Ajaran yanga paling dasar dalam agama yaitu tentang Tuhan. Karena itu, Tuhan merupakan pembahasan pokok dalam filsafat agama. Dimana filsafat agama Tuhan tidak hanya dibahas dari segi argumantasi tentang eksistensi-Nya, akan tetapi Tuhan juga akan dibahas tentang argumantasi orang-orang yang meragukan dan bahkan menolak terhadap eksistensi-Nya. ${ }^{31}$

\section{Kegunaan Filsafat Dalam Mempelajari Agama}

Filsafat adalah suatu analisis yang dilakukan secara hati-hati terhadap analogianalogi mengenai sebuah masalah dan penyusunan secara sistematis terhadap sebuah paradigma yang menjadi sebuah tindakan. Suatu agama akan mengungkapkan suatu kumpulan tingkah laku dan kepercayaan sebagai bentuk nilai-nilai yang sangat tinggi dan baik bagi para penganutnya. ${ }^{32}$ Kepercayaan terhadap agama, memiliki berbagai macam perbedaan diantara yaitu ateisme (tidak percaya adanya tuhan), monoteisme (percaya hanya pada satu tuhan) dan politeisme (percaya pada banyak tuhan). Meskipun demikian, sebagai seorang intelektual kita harus berhati-hati dalam menentukan kepercayaan kita pada setiap agama dan pilihlah sesuai dengan keyakinan yang akan mengantarkan kita pada kebaikan. ${ }^{33}$ Filsafat agama merupakan sebuah penyelidikan terhadap agama-agama yang ada di muka bumi ini yang berdasarkan makna istilah, bukti-bukti, dan prinsipprinsip yang ada dalam agama." Selain itu juga, filsafat agama juga membahas segala

\footnotetext{
28 Marhaeni Saleh, "Filsafat Agama Dalam Ruang Lingkupnya." h. 89.

${ }^{29}$ A. Susanto, Filsafat Ilmu. h. 78

30 Tamrin, "Relasi Ilmu, Filsafat Dan Agama Dalam Dimensi Filsafat Ilmu." h. 86.

${ }^{31}$ Dedi Supriyadi \& Mustofa Hasan, Filsafat Agama. h. 17.

32 Burhanuddin Salam, Pengantar Filsafat. h. 20.

33 Dedi Supriyadi \& Mustofa Hasan, Filsafat Agama. h. 30-31.
} 


\section{DIROSAT \\ Journal of Islamic Studies \\ Volume 6, No. 22021}

ISSN: 2541-1667 (print); 2541-1675 (online)

sesuatu yang berhubungan antar agama dengan lapangan pengetahuan manusia yang lain. ${ }^{34}$

Adapun kegunaan filsafat dalam agama adalah memahami sebuah makna agama, menambah sebuah pengetahuan tentang kepercayaan pada Tuhan dan dapat menunjukkan bukti-bukti Tuhan baik secara empiris maupun non-empiris." 35 Timbulnya sebuah tuntutan untuk mencari bukti adanya Tuhan disebabkan adanya perselisihan tentang argumen bahwa Tuhan itu tidak jelas secara panca indera. Nah, disinilah letak dari timbulnya sebuah masalah tentang adanya Tuhan. Dari sinilah timbul sebuah pembuktian tentang adanya tuhan baik dari kajian ontologis, epistimologis dan aksiologis. Dengan demikian bahwa kegunaan filsafat dalam mempelajari agama agar keyakinankeyakinan yang ada dalam diri manusia bisa dilakukan secara rasional bahwa agama itu sangat penting bagi kehidupan manusia.

\section{Penutup}

Dari beberapa uraian diatas, dapatlah diambil sebuah kesimpulan sebagai berikut: Pertama; filsafat agama adalah suatu pembahasan yang sangat mendalam tentang ajaranajaran yang ada dalam agama-agama dengan argumen-argumen yang rasional atau bahkan in-rasional. Kedua; bahwa hubungan antara filsafat dan agama sangat erat kaitannya, dikarenakan dengan pengetahuan ilmu filsafat akan mengantarkan seseorang pada agama yang diyakini kebenarannya dengan logis dan tidak ada keraguan. Ketiga; Adapun kegunaan filsafat dalam mempelajari agama yakni agar keyakinan yang ada dalam diri manusia bisa dilakukan secara rasional bahwa agama itu sangat penting dalam kehidupan diri manusia itu sendiri.

\section{Daftar Pustaka}

A. Susanto. Filsafat Ilmu. Jakarta: PT. Bumi Aksara, 2010.

Abbas, Nurlaelah. "Muhammad Abduh: Konsep Rasionalisme Dalam Islam." Jurnal Dakwah Tabligh 15, no. 1 (2014): 51-68.

Abd. Wahid. "Korelasi Agama, Filsafat Dan Ilmu." Jurnal Substantia 14, no. 2 (2012): 224231.

Budi Handriyanto. Islamisasi Sains. Jakarta: Pstaka Al-Kautsar, 2010.

Burhanuddin Salam. Pengantar Filsafat. Jakarta: PT. Bumi Aksara, 2012.

Dedi Supriyadi \& Mustofa Hasan. Filsafat Agama. 1st ed. Bandung: Pustaka Setia, 2012.

Hidayatullah, Syarif. "Relasi Filsafat Dan Agama (Perspektif Islam)." Jurnal Filsafat 16, no. 2 (2006): 128-148.

Hossein Nasr. Islam Dan Nestapa Manusia. Edited by Anas Mahyuddin. Bandung: Pustaka Mulia, 1983.

Iffan, Ahmad, Muhammad Ridho Nur, and Asrizal Saiin. "Konseptualisasi Moderasi Beragama Sebagai Langkah Preventif Terhadap Penanganan Radikalisme Di Indonesia." Perada 3, no. 2 (2020): 187.

Ismail SM. Paradigma Pendidikan Islam Prof. Dr. Syed Muhammad Naquib Al-Attas. Yogyakarta, 1999.

Kemas Badarudin. Filsafat Pendidikan Islam. Yogyakarta: Pustaka Pelajar, 2009.

\footnotetext{
${ }^{34}$ Iffan, Nur, and Saiin, "Konseptualisasi Moderasi Beragama Sebagai Langkah Preventif Terhadap Penanganan Radikalisme Di Indonesia." h. 23.

${ }^{35}$ Abd. Wahid, "Korelasi Agama, Filsafat Dan Ilmu." h. 56.
} 
Komaruzaman. "Studi Pemikiran Muhammad Abduh Dan Pengaruhnya Terhadap Pendidikan Di Indonesia." Tarbawi: Jurnal Keilmuan Manajemen Pendidikan 3, no. 01 (2017): 90-101.

Lexy J. Moleong. Metodologi Penelitian Kualitatif. Bandung: Remaja Rosdakarya, 2005.

Marhaeni Saleh. "Filsafat Agama Dalam Ruang Lingkupnya." Sulesana 6, no. 488 (2012): 2292.

Siagian, Sondang P. Filsafat Administrasi. Jakarta: Haji Masagung, 1987.

Sugiono. Metodologi Penelitian Pendidikan Kuantitatif-Kualitatif Dan R\&D. Bandung: Alfabeta, 2010.

Tamrin, Abu. "Relasi Ilmu, Filsafat Dan Agama Dalam Dimensi Filsafat Ilmu." SALAM: Jurnal Sosial dan Budaya Syar-i 6, no. 1 (2019): 71-96.

Wan Mohd Nor Wan Daud. Filsafat Dan Praktek Pendidikan Islam Syed Naquib Al-Attas. Bandung: Mizan, 2003. 